\title{
Anethole prevents hydrogen peroxide-induced apoptosis and collagen metabolism alterations in human skin fibroblasts
}

\author{
Anna Galicka • Rafał Krętowski · Jolanta Nazaruk • \\ Marzanna Cechowska-Pasko
}

Received: 5 March 2014 / Accepted: 15 May 2014/Published online: 5 June 2014

(C) The Author(s) 2014. This article is published with open access at Springerlink.com

\begin{abstract}
The collagen metabolism alterations triggered by reactive oxygen species are involved in the development of various connective tissue diseases and skin aging. This study was designed to examine whether $(E)$-anethole possesses a protective effect on $\mathrm{H}_{2} \mathrm{O}_{2}$-induced alterations in collagen metabolism as well as whether it can prevent apoptosis in human skin fibroblasts. In cells treated with $300 \mu \mathrm{M} \mathrm{H}_{2} \mathrm{O}_{2}$, a decrease in collagen biosynthesis of $54 \%$ was observed. Pretreatment of cells with $0.5 \mu \mathrm{M}$ anethole for $1 \mathrm{~h}$ completely prevented this alteration. Changes at the protein level positively correlated with alterations of type I collagen mRNA expression. We have shown that $\mathrm{H}_{2} \mathrm{O}_{2}$ caused increase in the activity of MMP-2 and MMP-9 as well as that an increase in MMP-2 activity can contribute to the $8 \%$ decrease in the amount of collagen secreted into the medium. The most efficient suppression of these changes was observed in the presence of $0.5 \mu \mathrm{M}$ of anethole. At $10 \mu \mathrm{M}$, in addition to suppression, an inhibitory effect of anethole on MMP-9 activity was documented. Additionally, the $60 \% \mathrm{H}_{2} \mathrm{O}_{2}$-induced decrease in cell viability was suppressed by $1 \mu \mathrm{M}$ of anethole and a 4-fold increase in cell apoptosis was suppressed by $0.5 \mu \mathrm{M}$ of anethole. Our results suggest that anethole, which is a small
\end{abstract}

\footnotetext{
A. Galicka $(\bowtie)$

Department of Medical Chemistry, Medical University of Bialystok, Białystok, Poland

e-mail: angajko@umb.edu.pl

R. Krętowski · M. Cechowska-Pasko

Department of Pharmaceutical Biochemistry, Medical

University of Bialystok, Białystok, Poland

J. Nazaruk

Department of Pharmacognosy, Medical University of Bialystok, Białystok, Poland
}

lipophilic and non-toxic molecule with the ability to prevent $\mathrm{H}_{2} \mathrm{O}_{2}$-induced collagen metabolism alterations and apoptosis in human skin fibroblasts, would prove useful in the development of effective agents in pharmacotherapy of oxidative stress-related skin diseases.

Keywords (E)-Anethole $\cdot$ Hydrogen peroxide . Collagen · Matrix metalloproteinases · Apoptosis · Human skin fibroblasts

\section{Introduction}

Hydrogen peroxide, like other reactive oxygen species (ROS), is generated at low levels during normal cellular metabolism. However, there is a lot of evidence for its damaging effects at higher concentrations on cells and components of the extracellular matrix (ECM) [1]. Because of its small size, its solubility and its lack of charge, $\mathrm{H}_{2} \mathrm{O}_{2}$ easily penetrates into cells and interacts with intracellular ions such as iron and copper, generating highly reactive radicals. These induce damage of cellular biomolecules such as lipids, nucleic acids, and proteins and are implicated in the pathogenesis of various human degenerative connective tissue diseases and pathological processes, including carcinogenesis or human skin aging [2, 3]. Alterations in the synthesis and degradation of collagen, the main component of extracellular matrix, triggered by ROS, may be responsible for the development of these pathological changes. Therefore, agents with the ability to scavenge ROS might be beneficial in the treatment of different diseases as well as in protecting health.

The most beneficial effects against diseases such as cancer, cardiovascular diseases, and neurodegenerative disorders were shown by dietary polyphenols, which have 
been widely studied for their strong antioxidant properties $[1,4]$. Essential oil constituents, especially phenolic volatile compounds also show antioxidant activity. They work due to their high reactivity with peroxyl radicals [5].

Essential oils are still a poorly recognized group of natural compounds with great biologic potential. Interesting properties have been demonstrated by $(E)$-anethole (later called anethole) (Fig. 1). This phenylpropanoid derivative [1-methoxy-4-(1-propenyl)benzene] is a major component of anise and fennel fruit essential oils, where its content is higher than $80 \%$. These essential oils are traditionally used in herbal medicine as expectorant and carminative drugs [6]. Contemporary studies show that anethole inhibits TNFinduced cellular responses, which leads, among others, to the suppression of inflammation and carcinogenesis. This compound also inhibits the production, or release, of cytokines, prostaglandins, and nitric oxide [7, 8].

It has been reported that, among its multidirectional action, anethole also exhibited antioxidant properties and caused moderate suppression of lipid peroxidation [9]. Its antioxidant activity, similar to other phenolic compounds, depends on the conjugate double bonds [7]. The aim of this study was to examine whether anethole has a protective effect on $\mathrm{H}_{2} \mathrm{O}_{2}$-induced alterations in collagen metabolism, as well as if it can prevent the apoptosis of human skin fibroblasts.

\section{Materials and methods}

\section{Plant material}

Anethole used for the study was obtained from a commercial anise fruit essential oil (Pollena-Aroma, Warsaw, Poland) using flash chromatographic separation on a silica gel column eluted with hexane and mixtures of hexane and diethyl ether (increasing polarity). Separation was monitored using gas chromatography (GC) and gas chromatography-mass spectrometry (GC-MS), and the purity of the obtained compound reached $99 \%$. GC and GC-MS were performed on a Perkin-Elmer AutoSystem XL equipped with a Perkin-Elmer TurboMass detector and a Perkin-Elmer Elite 5MS column, $30 \mathrm{~m} \times 250 \mu \mathrm{m}$ I.D., $1 \mu \mathrm{m}$ film thickness. Identification was carried out on the basis of comparing the mass spectrum of the compound with the mass spectrum listed by the NIST MS Library.

\section{Fibroblast cultures}

Human normal skin fibroblast cell line (CRL1474) was obtained from the American Type Culture Collection (ATCC). Cells were maintained in Dulbecco's modified Eagle's medium (DMEM) supplemented with $10 \%$ heat- inactivated fetal bovine serum GOLD (FBS GOLD), $2 \mathrm{mM}$ glutamine, penicillin $(100 \mathrm{U} / \mathrm{ml})$, and streptomycin $(100 \mu \mathrm{g} / \mathrm{ml})$. Cells were cultured in Falcon flasks (BD) in a $5 \% \mathrm{CO} 2$ incubator (Galaxy $\mathrm{S}+$ ), at $37{ }^{\circ} \mathrm{C}$. Subconfluent cultures were detached with $0.05 \%$ trypsin, $0.02 \%$ EDTA in calcium-free phosphate-buffered saline and counted in a Scepter cell counter (Millipore).

Estimation of biologic action of anethole in $\mathrm{H}_{2} \mathrm{O}_{2}$ treated and untreated skin fibroblasts

Cells $\left(2.5 \times 10^{5}\right)$ were seeded in six-well plates. Confluent cells were preincubated in a fresh serum-free medium for $2 \mathrm{~h}$. The anethole dissolved in DMSO was added to the medium to a final concentration of $0.5,1$, and $10 \mu \mathrm{M}$ and incubated for $24 \mathrm{~h}$. The same concentration of DMSO solution $(0.01 \%)$ was used as control in order to rule out the possible effect of DMSO on fibroblasts. In experiments on the protective role of anethole against the destructive action of $\mathrm{H}_{2} \mathrm{O}_{2}$, cells were treated with $300 \mu \mathrm{M}$ of $\mathrm{H}_{2} \mathrm{O}_{2}$ for $24 \mathrm{~h}$ or, prior to $\mathrm{H}_{2} \mathrm{O}_{2}$ delivery, pretreated with anethole for $1 \mathrm{~h}$ and incubated over $24 \mathrm{~h}$. After incubation, the exposure medium was removed and stored for analysis of collagen content and matrix metalloproteinases (MMPs) activity. The monolayers were washed three times with sterile $10 \mathrm{mM}$ PBS $\mathrm{pH} 7.4$, and cell membranes were disrupted using sonicator (Sonics Vibra cell). Aliquots of the homogenate were used for collagen and protein measurement as well as for RNA isolation. A BCA Protein Assay Kit (Pierce) was used for a protein concentration measurement.

\section{Collagen biosynthesis assay}

$5 \mu \mathrm{Ci} \mathrm{L}-\left[5-{ }^{3} \mathrm{H}\right]$ Proline $(28 \mathrm{Ci} / \mathrm{mmol})$ was added to skin fibroblast cultures treated with only $\mathrm{H}_{2} \mathrm{O}_{2}$ and to one pretreated with anethole, and then incubated for $24 \mathrm{~h}$. Incorporation of radioactive precursor into collagen was determined by digestion of the proteins with purified Clostridium histolyticum collagenase in accordance with the method developed by Peterkofsky et al. [10]. Secretion of collagen was estimated as the distribution of protein between the cell layer and the medium.

\section{MMPs assay}

Gelatinolytic activity of the media was determined according to the method of Unemori and Werb [11]. Equal amounts $(10 \mu \mathrm{g})$ of protein were electrophoresed under non-reducing conditions in $10 \%$ polyacrylamide gel impregnated with $1 \mathrm{mg} / \mathrm{ml}$ gelatin (Sigma) as a substrate. After electrophoresis the gel was washed twice for $15 \mathrm{~min}$ with $2 \%$ Triton X-100 and then incubated overnight at $37^{\circ}$ 
$\mathrm{C}$ in $50 \mathrm{mM}$ Tris $/ \mathrm{HCl}, \mathrm{pH} 8.0$, containing $5 \mathrm{mM} \mathrm{CaCl}_{2}$. The gel was stained with $0.5 \%$ coomassie brilliant blue R-250. Clear bands on the blue background, representing areas of substrate-degrading enzymes, were quantified using an imaging densitometer (G:BOX, Syngene).

\section{Real-time PCR}

Total RNA was isolated using the MasterPure ${ }^{\mathrm{TM}}$ RNA purification kit (Akor Laboratories). The RNA extracts were treated with RNase-free DNase I to remove contaminating DNA, quantified on a spectrophotometer (Nanodrop 2000, ThermoScientific) and stored at $-80{ }^{\circ} \mathrm{C}$. Real-time PCR assays performed in CFX96 Real-time system (Bio-Rad) were used to quantify mRNA levels of type I collagen. The gene GAPDH (glyceraldehyde-3phosphate dehydrogenase) was evaluated as housekeeping. Total RNA $(1 \mu \mathrm{g})$ in the total volume of $20 \mu \mathrm{l}$ was reverse transcribed using a Tetro cDNA Synthesis Kit (Bioline) and $1 \mu \mathrm{loligo}(\mathrm{dT})$ primer. Real-time PCR was carried out using $2 \mu \mathrm{l}$ of the cDNA product, $400 \mathrm{nM}$ each of the primer and the SensiFAST ${ }^{\mathrm{TM}}$ SYBR Kit (Bioline). The primers used for type I collagen (COLIAl gene) were: forward 5'-ATG TCT AGG GTC TAG ACA TGT TCA-3', reverse $5^{\prime}$-CCT TGC CGT TGT CGC AGA CG-3' and for GAPDH they were: forward 5'-CAT GAC AAC TTT GGT ATC GTG G- $3^{\prime}$ and reverse $5^{\prime}$-CCT GCT TCA CCA CCT TCT TG-3' [12]. Cycling parameters were: $95{ }^{\circ} \mathrm{C}$ for $1 \mathrm{~min}$ to activate the DNA polymerase, then 40 cycles of denaturation for $10 \mathrm{~s}$ at $95{ }^{\circ} \mathrm{C}$, annealing for $15 \mathrm{~s}$ at $60^{\circ} \mathrm{C}$, and extension for $20 \mathrm{~s}$ at $72{ }^{\circ} \mathrm{C}$. The reaction was then subjected to a melting protocol from $55^{\circ} \mathrm{C}$ to $95{ }^{\circ} \mathrm{C}$ with a $0.2{ }^{\circ} \mathrm{C}$ increment and $1 \mathrm{~s}$ holding at each increment to check the specificity of the amplified products. Single product formation was confirmed by melting point analysis and agarose gel electrophoresis. For negative control, water instead of mRNA samples was used. Samples were run in triplicate and the $\Delta \Delta C T$ method was applied for statistical analysis of the CT-values. The relative gene expression levels were standardized with those measured in the untreated control.

Assay for cell viability

The assay was performed according to the method developed by Carmichael et al. [13] using MTT [3-(4,5dimethylthiazol-2-yl)-2,5-diphenyltetrazolium bromide]. Briefly, cells were seeded in a 24 -well plate at a density of $10^{4}$ per well. Confluent cells cultured with tested compounds for $24 \mathrm{~h}$ at $37^{\circ} \mathrm{C}$ were washed three times with PBS and then incubated for $4 \mathrm{~h}$ with $1 \mathrm{ml}$ of MTT solution $(0.25 \mathrm{mg} / \mathrm{ml}$ in PBS). The medium was removed, and $1 \mathrm{ml}$ of $0.1 \mathrm{M} \mathrm{HCl}$ in absolute isopropanol was added.<smiles>C/C=C/c1ccc(OC)cc1</smiles>

(E)-anethole

Fig. 1 Chemical structure of anethole

Absorbance of converted dye in living cells was measured at a wavelength of $570 \mathrm{~nm}$.

Detection of apoptosis

Apoptosis was evaluated using flow cytometry on a FACSCanto II cytometer (Becton-Dickinson). Cells were trypsinized, resuspended in DMEM and then in a binding buffer. Next, the cells were stained with FITC Annexin V and PI for $15 \mathrm{~min}$ at room temperature in the dark following the manufacturer's instructions (FITC Annnexin V apoptosis detection Kit I). Data were analyzed with FACSDiva software and dead cells were excluded based on forward- and side-scatter parameters.

\section{Statistical analysis}

In all the experiments, the mean values for three assays \pm SD were calculated. The results were subjected to statistical analysis using the one-way analysis of variance (ANOVA) followed by the Duncan's multiple range post hock test. Differences were recognized as statistically significant at $P<0.05$. Spearman rank correlation analysis was conducted to investigate the relationship between the degrading of collagen enzymes and collagen expression in the media. Correlations were considered statistically significant at $P<0.05$. All the calculations were performed using the Statistica 9.0 package (StatSoft, Tulsa, OK, USA).

\section{Results}

The effects of $\mathrm{H}_{2} \mathrm{O}_{2}$ treatment on cell viability

Treatment of human skin fibroblasts with $300 \mu \mathrm{M}$ of $\mathrm{H}_{2} \mathrm{O}_{2}$ induced a decrease of cell viability by $60 \%$ as compared to the control (Fig. 2). Pretreatment of cells prior to $\mathrm{H}_{2} \mathrm{O}_{2}$ delivery with $1 \mu \mathrm{M}$ of anethole caused a 2-fold increase in cell growth compared to $\mathrm{H}_{2} \mathrm{O}_{2}$ treatment alone, suggesting that anethole suppressed the $\mathrm{H}_{2} \mathrm{O}_{2}$-induced cytotoxicity. Anethole used at a higher concentration of $10 \mu \mathrm{M}$ prevented cytotoxicity to comparable extent as $0.5 \mu \mathrm{M}$ of the 


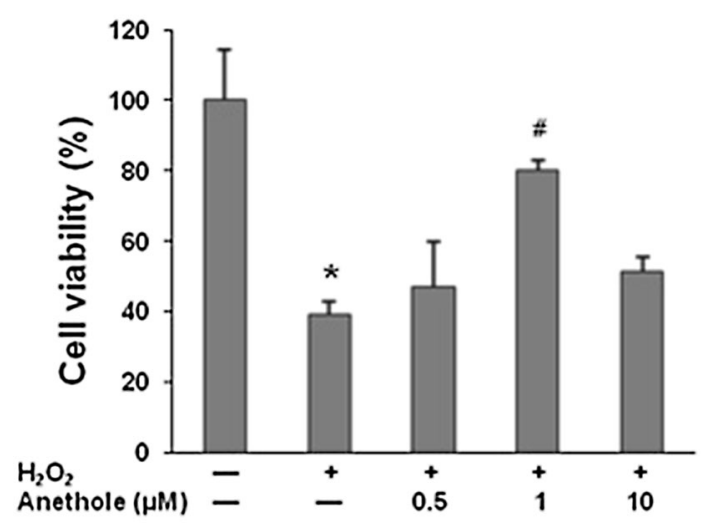

Fig. 2 Effect of anethole on $\mathrm{H}_{2} \mathrm{O}_{2}$-induced cytotoxicity in human skin fibroblasts. Cells were pretreated with anethole for $1 \mathrm{~h}$ and then exposed to $300 \mu \mathrm{M} \mathrm{H}_{2} \mathrm{O}_{2}$ for $24 \mathrm{~h}$. Values \pm standard deviation (SD) are the mean of triplicate cultures. ${ }^{*} P<0.01$, no treatment versus control $\mathrm{H}_{2} \mathrm{O}_{2} ;{ }^{\#} \mathrm{P}<0.01$, control versus anethole
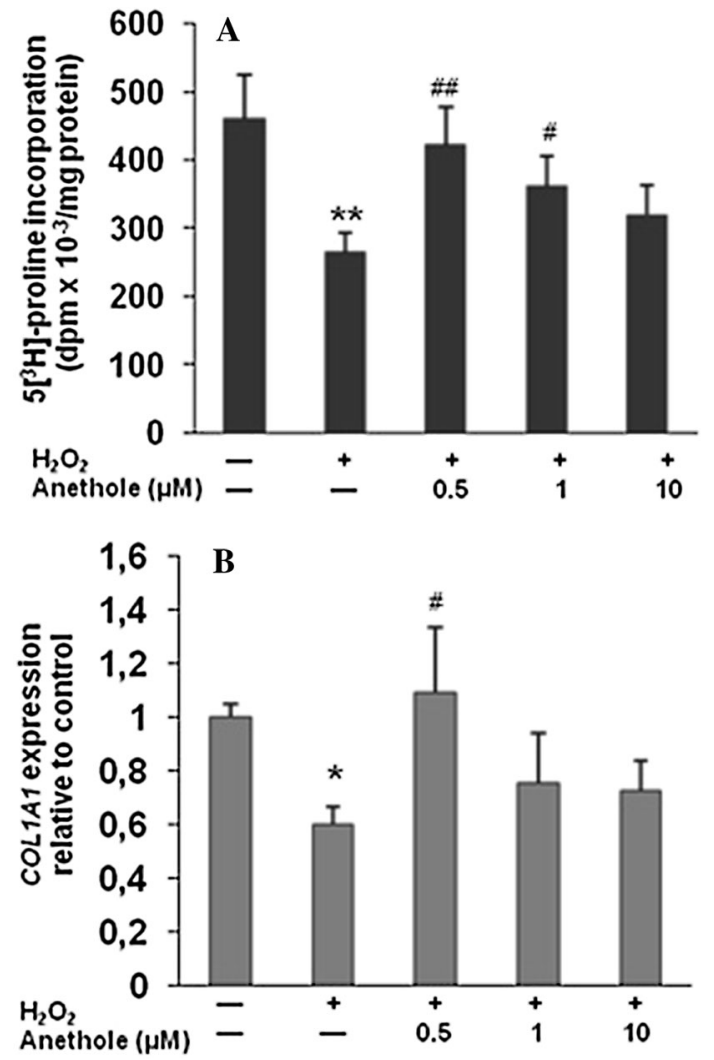

Fig. 3 Effect of anethole on $\mathrm{H}_{2} \mathrm{O}_{2}$-induced changes in collagen biosynthesis (A) and the expression of COL1A1 gene (B) in human skin fibroblasts. Cells were incubated with anethole for $1 \mathrm{~h}$ and then exposed to $300 \mu \mathrm{M} \mathrm{H} \mathrm{H}_{2} \mathrm{O}_{2}$ for $24 \mathrm{~h}$. $* P<0.05$, ** $P<0.01$ no treatment versus control $\mathrm{H}_{2} \mathrm{O}_{2} ;{ }^{\#} P<0.05,{ }^{\# \#} P<0.01$ control versus anethole. Values \pm standard deviation (SD) are the mean of triplicate cultures

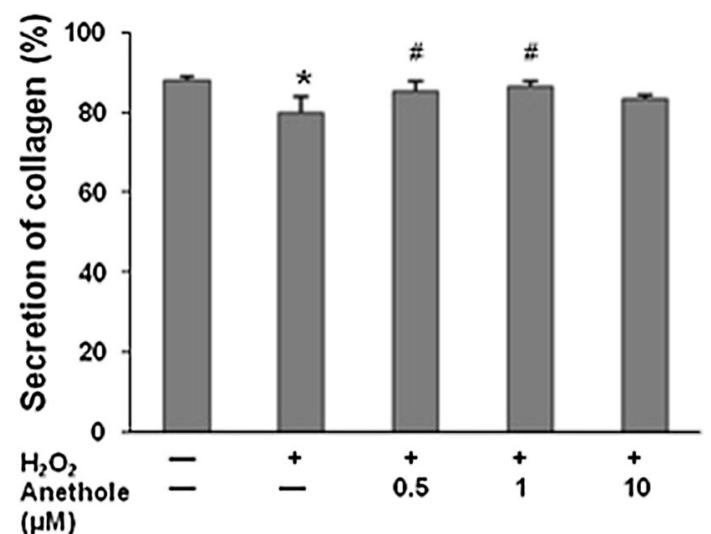

Fig. 4 Effect of anethole on collagen secreted into media in the presence of $\mathrm{H}_{2} \mathrm{O}_{2}$. Skin fibroblasts were pretreated with anethole for $1 \mathrm{~h}$ and then exposed to $300 \mu \mathrm{M} \mathrm{H}_{2} \mathrm{O}_{2}$ for $24 \mathrm{~h}$. Values \pm standard deviation (SD) are the mean of triplicate cultures. $* P<0.01$, no treatment versus control $\mathrm{H}_{2} \mathrm{O}_{2} ;{ }^{\#} P<0.05$, control versus anethole

compound. Furthermore, anethole alone did not affect viability of cells at concentrations up to $100 \mu \mathrm{M}$ (data not shown).

Suppression of $\mathrm{H}_{2} \mathrm{O}_{2}$-induced decrease in collagen biosynthesis and MMPs activity increase

Collagen biosynthesis in skin fibroblasts was measured using L- $\left[5-{ }^{3} \mathrm{H}\right]$ proline incorporation into proteins [10]. In cells treated with $300 \mu \mathrm{M}$ of $\mathrm{H}_{2} \mathrm{O}_{2}$, a significant decrease in collagen biosynthesis (by $54 \%$ ) as compared to untreated cells was demonstrated (Fig. 3A). Pretreatment of cells prior to $\mathrm{H}_{2} \mathrm{O}_{2}$ delivery with anethole prevented collagen biosynthesis decrease. With anethole at concentrations of 0.5 and $1 \mu \mathrm{M}$, a significant increase in collagen content, by 59.6 and $36.5 \%$, respectively, compared to $\mathrm{H}_{2} \mathrm{O}_{2}$ treatment alone, was observed. The results of the protective effect of anethole on collagen in $\mathrm{H}_{2} \mathrm{O}_{2}$-treated cells at the protein level positively correlated with its effect on collagen at the mRNA level $(r=0.528, P<0.05)$, as was assessed using real-time PCR (Fig. 3B). Secretion of collagen was estimated as the distribution of protein between the cell layer and the medium. The percentage of collagen secreted into the medium was estimated at $87 \%$ for the untreated cells. We observed a decrease in collagen secretion of up to $79 \%$ for cells treated with $300 \mu \mathrm{M}$ of $\mathrm{H}_{2} \mathrm{O}_{2}$ (Fig. 4). Exposure of the cells to 0.5 and $1 \mu \mathrm{M}$ of anethole before treatment with $\mathrm{H}_{2} \mathrm{O}_{2}$ resulted in the normalization of the amount of collagen secreted into the medium. 
$\mathbf{A}$
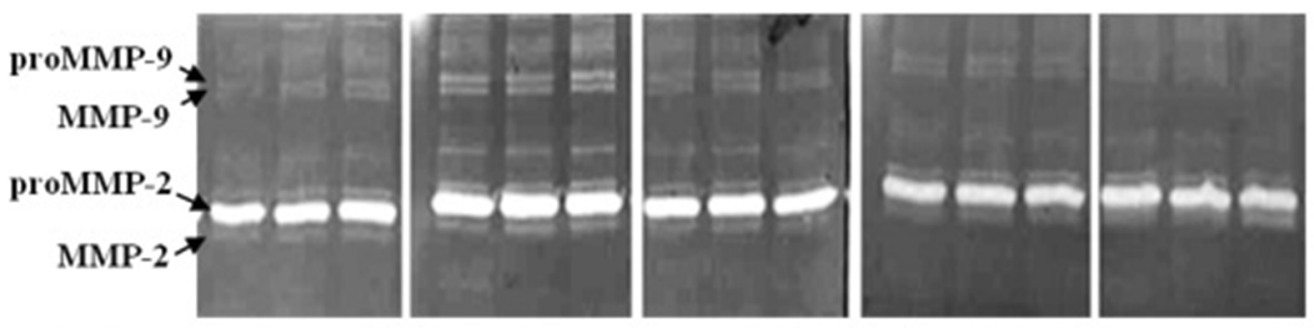

$\begin{array}{ll}\mathrm{H}_{2} \mathrm{O}_{2} & - \\ \text { Anethole }(\mu \mathrm{M}) & -\end{array}$

$\pm$

$\stackrel{+}{0.5}$

$+$

$+$

B

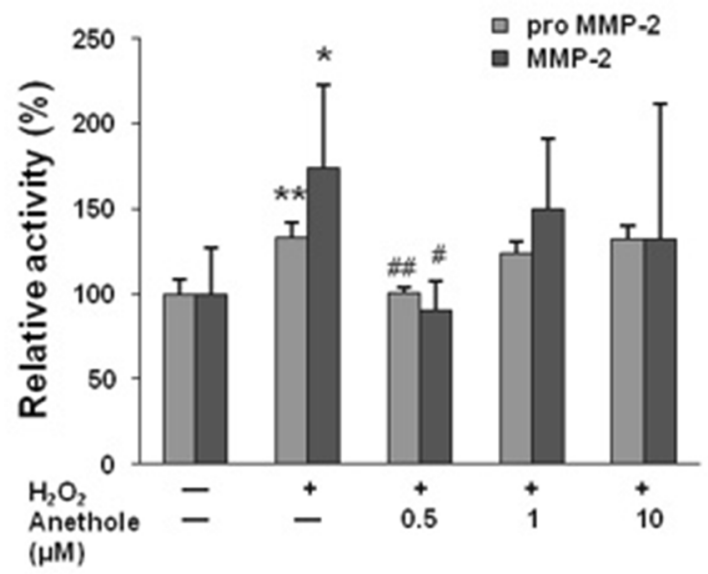

Fig. 5 Protective effect of anethole on $\mathrm{H}_{2} \mathrm{O}_{2}$-induced increase in gelatinases activity in human skin fibroblasts. A Representative zymography of pro- and active forms of MMP-2 and MMP-9. B Densitometric intensity of the zymography bands expressed as percentage of the control. Skin fibroblasts were pretreated with

It has been shown that ROS cause an increase in the activity of matrix metalloproteinases (MMPs) which degrade collagen in skin fibroblasts $[14,15]$. Therefore, we treated cells with $0.3 \mathrm{mM} \mathrm{H}_{2} \mathrm{O}_{2}$ and studied whether anethole can protect them against changes in MMPs activity induced by $\mathrm{H}_{2} \mathrm{O}_{2}$. Using zymography and gelatin as a substrate, we detected the presence of pro-MMP-2 $(72 \mathrm{kDa})$ and pro-MMP-9 $(95 \mathrm{kDa})$ and their active forms $(66 \mathrm{kDa})$ and $(88 \mathrm{kDa})$, respectively (Fig. 5A). As was demonstrated by densitometry, $\mathrm{H}_{2} \mathrm{O}_{2}$ caused an increase in the activity of both forms of MMP-2 (72 and $66 \mathrm{kDa})$ by 33 and $73 \%$, respectively (Fig. 5B). After pretreatment of cells with anethole, the greatest protection of pro-MMP-2 and its active form against $\mathrm{H}_{2} \mathrm{O}_{2}$ action was demonstrated at concentration of $0.5 \mu \mathrm{M}$ (a decrease of 33 and $83 \%$, respectively). Negative correlations occurred between collagen measured using $\mathrm{L}-\left[5-{ }^{3} \mathrm{H}\right]$ proline incorporation (Fig. 3A) and pro-MMP-2 $(r=-0.828, P<0.01)$, as well as its active form $(r=-0.639, P<0.05)$ (Fig. 5).

Similarly to MMP-2, we observed an influence of $\mathrm{H}_{2} \mathrm{O}_{2}$ on both forms of MMP-9 (95 and $88 \mathrm{kDa}$ ), however in a

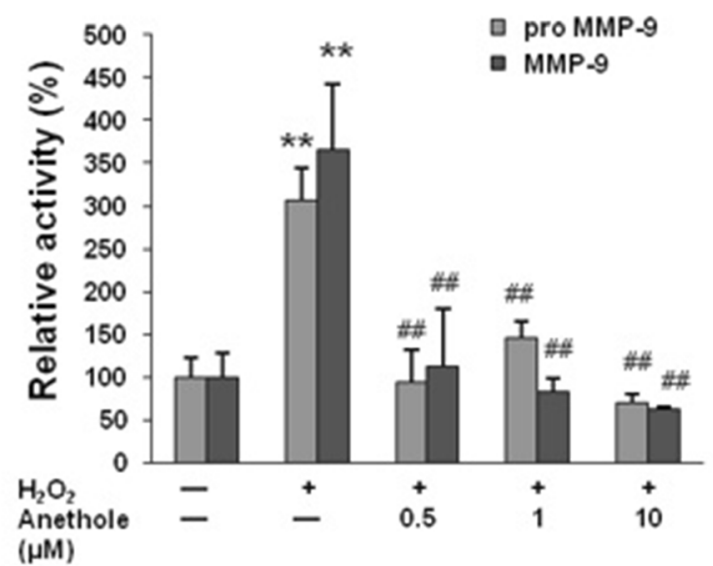

anethole for $1 \mathrm{~h}$ and then exposed to $300 \mu \mathrm{M} \mathrm{H} \mathrm{H}_{2} \mathrm{O}_{2}$ for $24 \mathrm{~h}$. Values \pm standard deviation (SD) are the mean of triplicate cultures. ${ }^{*} P<0.05,{ }^{* *} P<0.01$ no treatment versus control $\mathrm{H}_{2} \mathrm{O}_{2} ;{ }^{*} P<0.05$, ${ }^{\# \#} P<0.01$ control versus anethole

much more drastic way (a 3- and 3.6-fold increase, respectively) (Fig. 5B). Anethole used at all concentrations significantly inhibited the increase in the intensity of both bonds corresponding to the molecular masses of both forms of MMP-9. However, the most efficient suppression was observed at $0.5 \mu \mathrm{M}$. It is worth adding that anethole at concentration of $10 \mu \mathrm{M}$ inhibited activity of 95 and $88 \mathrm{kDa}$ of MMP-9 by 30 and $38 \%$, respectively, in relation to untreated controls. In contrast to MMP-2, no significant correlations between synthesized collagen and MMP-9 activity were detected.

The effect of anethole on $\mathrm{H}_{2} \mathrm{O}_{2}$-induced apoptosis

It has been reported that hydrogen peroxide, like other ROS, can increase the apoptosis of human skin fibroblasts $[16,17]$. Apoptosis was estimated in cells treated with $\mathrm{H}_{2} \mathrm{O}_{2}$ and pretreated with anethole at different concentrations prior to $\mathrm{H}_{2} \mathrm{O}_{2}$ delivery using an FITC Annexin V and flow cytometry detection. Incubation of fibroblasts with $300 \mu \mathrm{M}$ of $\mathrm{H}_{2} \mathrm{O}_{2}$ for $24 \mathrm{~h}$ resulted in a 4 -fold increase in 
Fig. 6 Effect of anethole on $\mathrm{H}_{2} \mathrm{O}_{2}$-induced apoptosis of human skin fibroblasts. A Representative flow cytometric analysis using two color staining with annexin V-FITC and PI. B Percentage of apoptotic cells. Cells were pretreated with anethole for $1 \mathrm{~h}$ and then exposed to $300 \mu \mathrm{M}$ $\mathrm{H}_{2} \mathrm{O}_{2}$ for $24 \mathrm{~h}$.

Values \pm standard deviation (SD) are the mean of triplicate cultures. $* P<0.01$ no treatment versus control $\mathrm{H}_{2} \mathrm{O}_{2}$; ${ }^{\#} P<0.01$ control versus anethole
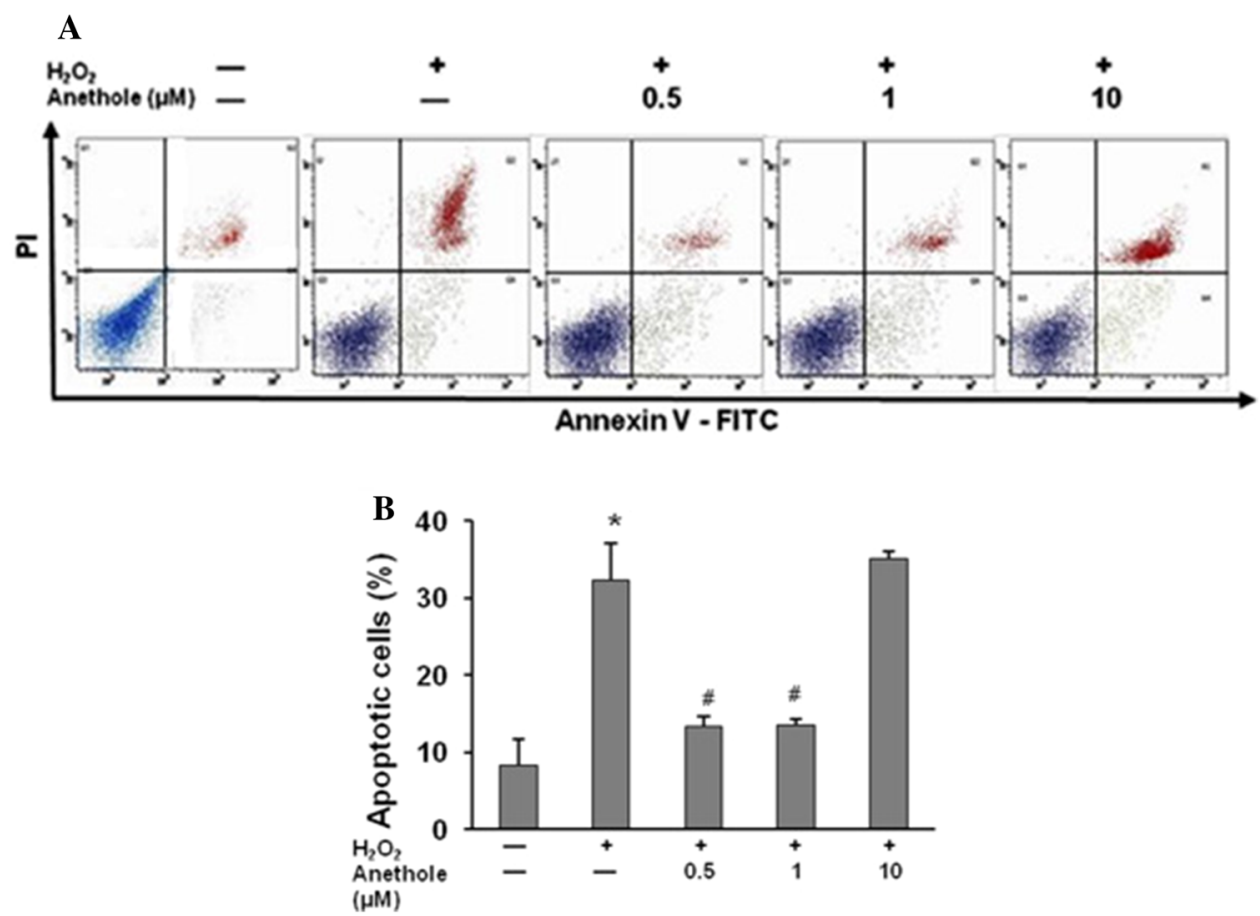

the percentage of apoptotic cells (Fig. 6). It is worthy of note that anethole, at concentrations of 0.5 and $1 \mu \mathrm{M}$ but not at $10 \mu \mathrm{M}$, significantly decreased apoptosis in comparison to cells incubated with $\mathrm{H}_{2} \mathrm{O}_{2}$.

\section{Discussion}

Oxidative stress can be generated in the connective tissue of the skin during its UV radiation, inflammatory processes like wound healing, and in skin aging [1-3]. The most promising treatments of these pathological changes include herbal extracts, vitamins, and antioxidant food supplements, which have been reported widely to scavenge free radicals from skin cells $[1,4,17,18]$.

It has been shown that hydrogen peroxide, like other reactive oxygen species, plays a substantial role in the metabolism of the main component of ECM, collagen [14, $19,20]$. We also found that hydrogen peroxide used at concentration of $0.3 \mathrm{mM}$ caused a decrease in collagen biosynthesis in human skin fibroblasts by $54 \%$. Pretreatment of cells with anethole at a low concentration of $0.5 \mu \mathrm{M}$ completely prevented this alteration. These changes at the protein level were correlated with alterations in the mRNA expression of type I collagen, and is in agreement with other studies $[14,20]$. Anethole at the concentration of $0.5 \mu \mathrm{M}$ totally abrogated the $\mathrm{H}_{2} \mathrm{O}_{2}$-induced alteration of COL1A1 gene.

Extracellular collagen plays an important role in the maintenance of the structural integrity of ECM, and its level is determined by the balance between synthesis and degradation [21]. MMPs, which are zinc-dependent endopeptidases, degrade components of ECM and, therefore, play an important role in physiologic and pathological remodeling [22]. MMP-2 (gelatinase A) and MMP-9 (gelatinase B) are key enzymes in the degradation of ECM collagen and are regulated through activation of latent proenzymes (pro-MMPs).

In our study we have shown that $\mathrm{H}_{2} \mathrm{O}_{2}$ exhibited a stimulating effect on the activity of both MMP-2 forms (72 and $66 \mathrm{kDa}$ ) (33 and $73 \%$, respectively) and that $0.5 \mu \mathrm{M}$ of anethole completely protected against these changes. These results suggest that the effect of hydrogen peroxide was mediated by the induction of MMP-2 synthesis and activation at the translational and post-translational level. There is evidence that $\mathrm{H}_{2} \mathrm{O}_{2}$ is involved in the induction of MMP-2 at the mRNA level [14, 15]. Furthermore, the authors reported that $\mathrm{H}_{2} \mathrm{O}_{2}$ not only directly activates MMPs, but also causes a decrease in the expression of their inhibitors, such as TIMP2. The significant negative correlations between collagen content and MMP-2 activity, which have been found in our study, suggest that the increase in enzyme activity can contribute to the decrease in collagen synthesized in $\mathrm{H}_{2} \mathrm{O}_{2}$-treated cells. MMP-2 is known to digest native type I collagen and generate the 3/4and 1/4-fragments characteristic of vertebrate collagenases [23].

Similarly, both forms of MMP-9 (95 and $88 \mathrm{kDa}$ ) were significantly influenced by hydrogen peroxide, much more than MMP-2, since a 3- and 3.6-fold increase in their 
activity, respectively, was observed. Anethole at all concentrations used $(0,5,1$, and $10 \mu \mathrm{M})$ significantly inhibited the increase in the intensity of both bonds corresponding to the molecular masses of MMP-9, with the most efficient suppression demonstrated at $0.5 \mu \mathrm{M}$. Furthermore, anethole at concentration of $10 \mu \mathrm{M}$ inhibited the activity of both 95 and $88 \mathrm{kDa}$ MMP-9 by 30 and $38 \%$, respectively, in comparison to the untreated control. It has been reported that anethole used at a higher concentrations of 50 and $100 \mu \mathrm{M}$ inhibited the activity of both MMP-2 and MMP-9 in HT 1080 cells suggesting its antimetastatic activity [24]. However, in contrast to MMP-2, no significant correlations between collagen content in the medium and MMP-9 activity were detected.

We also examined the effect of anethole on $\mathrm{H}_{2} \mathrm{O}_{2}$ induced cytotoxicity and apoptosis of skin fibroblasts. Treatment of cells with $0.3 \mathrm{mM} \mathrm{H}_{2} \mathrm{O}_{2}$ significantly decreased viability of cells compared with the control cultures, confirming previous data of its toxic effect on fibroblasts $[15,25,26]$. Anethole significantly suppresses the $\mathrm{H}_{2} \mathrm{O}_{2}$-induced cytotoxicity at a concentration of $1 \mu \mathrm{M}$. We did not observe a more efficient prevention at higher concentrations. Several authors have reported that hydrogen peroxide can induce apoptosis in fibroblast cell cultures $[16,17,26]$. In our study, after a $24 \mathrm{~h}$ treatment of cells with $300 \mu \mathrm{M}$ of $\mathrm{H}_{2} \mathrm{O}_{2}$, the percent of apoptotic cells increased 4-times and apoptosis was significantly attenuated by anethole at concentrations of 0.5 and $1 \mu \mathrm{M}$.

It is well known that a decrease in the content of dermal collagen, a major ECM protein, results in the loss of tensile strength and elasticity of skin, increases its fragility, and impaired wound healing, all of which are characteristic of aged skin. Skin aging has general relevance for many degenerative connective tissue diseases such as osteoarthritis, osteoporosis, and arteriosclerosis [1-3]. Therefore, agents with the ability to scavenge ROS, elevate ECM collagen levels or inhibit major collagen-degrading enzymes, would be useful in the development of effective agents in pharmacotherapy of various connective tissue diseases.

Components of essential oils containing a phenol group in their structure have considerable antioxidant properties. It has been shown in experiments that the volatile fractions of Thymus sp. and Eugenia sp. and their main components thymol and eugenol are strong antioxidants with activity comparable to BHT and even higher [27].

Phenylpropanoids, to which anethole belongs, work either by direct scavenging of reactive oxygen species or by acting as chain-breaking peroxyl radical scavengers [28]. Anethole might chelate the zinc ion present in the catalytic site of MMPs and directly inhibit their activities, as well as exerting its antioxidant effects and inhibit their activity by attenuating oxidative stress. This is because oxidative stress activates nuclear factor Kappa B (NF- $\kappa$ B), an oxidant sensitive transcriptional factor, which plays a crucial role in the expression of MMP-2 as well as type I collagen $[24,29]$. It has been determined that anethole at a concentration of $1 \mathrm{mM}$ completely blocks NF- $\kappa \mathrm{B}$ activation induced by TNF, phorbol ester, ceramide, or okadaic acid and partially by $\mathrm{H}_{2} \mathrm{O}_{2}$ [7]. In contrast, in our study, anethole was effective at a concentration lower than $1 \mu \mathrm{M}$. Anethole and its sulfated analogs have also been shown to increase the level of cellular glutathione (GSH) which, as an endogenous antioxidant, plays a key role in the protection against ROS damage [30].

It is worth mentioning that the majority of recently introduced antioxidants is hydrophilic, which inhibits membrane passage and their antioxidant applications. Essential oils can be absorbed through the skin. This process is not active but occurs by simple diffusion, therefore, volatile components must be in contact with the skin for a certain period of time. They also reach the bloodstream, and, for example, anethole is expelled with the air breathed out after about $20-40 \mathrm{~min}$. Anethole is a small, lipophilic molecule which permeates through cell membranes. It is worth noticing that $(E)$-anethole is non-toxic, non-irritant, and non sensitizing. It has no genotoxic activity and is not significantly carcinogenic [31].

In conclusion, the results of the present study indicate that anethole exhibits protective properties against hydrogen peroxide-induced toxicity and collagen metabolism changes in human skin fibroblast cultures, which can suggest its therapeutic properties in oxidative stress-related skin diseases. However, further study is needed to elucidate the exact mechanism of this action.

Acknowledgements This study was conducted with the use of equipment purchased by the Medical University of Bialystok as part of the OP DEP 2007-2013, Priority Axis I.3, contract No POPW.01.03.00-20-022/09.

Open Access This article is distributed under the terms of the Creative Commons Attribution License which permits any use, distribution, and reproduction in any medium, provided the original author(s) and the source are credited.

\section{References}

1. Valko M, Leibfritz D, Moncol J, Cronin MT, Mazur M, Telser J (2007) Free radicals and antioxidants in normal physiological functions and human disease. Int J Biochem Cell Biol 39:44-84

2. Barja G (2004) Free radicals and aging. Trends Neurosci 27:595-600

3. Aruoma OI (1998) Free radicals, oxidative stress, and antioxidants in human health and disease. JAOCS 75:199-212

4. Mukherjee PK, Maity N, Nema NK, Sarkar BK (2011) Bioactive compounds from natural resources against skin aging. Phytomedicine 19:64-73 
5. Amorati R, Foti MC, Vaglimigli L (2013) Antioxidant activity of essential oils. J Agric Food Chem 61:10835-10847

6. Evans WC (1996) Trease and Evans' pharmacognosy, 14th edn. WBSaunders Company Ltd, London

7. Chainy GBN, Manna SK, Chaturvedi MM, Aggarwal BB (2000) Anethole blocks both early and late cellular responses transduced by tomor necrosis factor: effect on NF- $\mathrm{BB}, \mathrm{AP}-1$, JNK, MAPKK and apoptosis. Oncogene 19:2943-2950

8. Ritter AMV, Domiciano TP, Verri WA Jr, Zarpelon AC, da Silva LG, Barbosa CP, Natali MR, Cuman RK, Bersani-Amado CA (2013) Antihypernociceptive activity of anethole in experimental inflammatory pain. Inflammopharmacology 21:187-197

9. Naderi GA, Asgary S, Ani M, Sarraf-Zadegan N, Safar MR (2004) Effect of some volatile oils on the affinity of intact and oxidized low-density lipoproteins for adrenal cell surface receptors. Mol Cell Biochem 267:59-66

10. Peterkofsky B, Chojkier M, Bateman J (1982) Determination of collagen synthesis in tissue and cell culture system. In: Furthmay M (ed) Immunochemistry of the extracellular matrix. CRC Press, Boca Raton, pp 19-47

11. Unemori EN, Werb Z (1986) Reorganization of polymerized actin: a possible trigger for induction of procollagenase in fibroblasts cultured in and on collagen gels. J Cell Biol 103:1021-1031

12. Tancred TM, Belch AR, Reiman T, Pilarski LM, Kirshner J (2009) Altered expression of fibronectin and collagens I and IV in multiple myeloma and monoclonal gammopathy of undetermined significance. J Histochem Cytochem 57:239-247

13. Carmichael J, Degraff W, Gazdar A, Minna J, Mitchell J (1987) Evaluation of a tetrazolinium-based semiautomated colorimetric assay: assessment of chemosensitivity testing. Cancer Res 47:936-942

14. Zaw KK, Yokoyama Y, Abe M, Ishikawa O (2006) Catalase restores the altered mRNA expression of collagen and matrix metalloproteinases by dermal fibroblasts exposed to reactive oxygen species. Eur J Dermatol 16:375-379

15. Kawaguchi Y, Tanaka H, Okada T, Konishi H, Takahashi M, Ito M, Asai J (1996) The effects of ultraviolet A and reactive oxygen species on the mRNA expression of 72-kDa type IV collagenase and its tissue inhibitor in cultured human dermal fibroblasts. Arch Dermatol Res 288:39-44

16. Bladier C, Wolvetang EJ, Hutchinson P, de Haan JB, Kola I (1997) Response of a primary human fibroblast cell line to $\mathrm{H}_{2} \mathrm{O}_{2}$ : senescence-like growth arrest or apoptosis? Cell Growth Differ 8:589-598

17. Duarte TL, Jones GD (2007) Vitamin C modulation of $\mathrm{H}_{2} \mathrm{O}_{2^{-}}$ induced damage and iron homeostasis in human cells. Free Radic Biol Med 43:1165-1175

18. Mukherjee PK, Maity N, Nema NK, Sarkar BK (2011) Bioactive compounds from natural resources against skin aging. Phytomedicine 19:64-73
19. Tanaka H, Okada T, Konishi H, Tsuji T (1993) The effect of reactive oxygen species on the biosynthesis of collagen and glycosaminoglycans in cultured human dermal fibroblasts. Arch Dermatol Res 285:352-355

20. Siwik DA, Pagano PJ, Colucci WS (2001) Oxidative stress regulates collagen synthesis and matrix metalloproteinase activity in cardiac fibroblasts. Am J Physiol Cell Physiol 280:C53-C60

21. Gelse K, Poschl E, Aigner T (2003) Collagens-structure, function, and biosynthesis. Adv Drug Deliv Rev 55:1531-1546

22. Nagase H, Visse R, Murphy G (2006) Structure and function of matrix metalloproteinases and TIMPs. Cardiovasc Res 69:562-573

23. Aimes RT, Quigley JP (1995) Matrix metalloproteinase-2 is an interstitial collagenase. Inhibitor-free enzyme catalyzes the cleavage of collagen fibrils and soluble native type I collagen generating the specific 3/4- and 1/4-length fragments. J Biol Chem 270:5872-5876

24. Choo EJ, Rhee Y-H, Jeong S-J, Lee H-J, Kim HS, Ko HS, Kim J-H, Kwon T-R, Jung JH, Kim JH, Lee H-J, Lee E-O, Kim DK, Chen C-Y, Kim S-H (2011) Anethole exerts antimetastatic activity via inhibition of matrix metalloproteinase 2/9 and AKT/ mitogen-activated kinase/nuclear factor kappa B signaling pathways. Biol Pharm Bull 34:41-46

25. Loo AE, Halliwell B (2012) Effects of hydrogen peroxide in a keratinocyte-fibroblast co-culture model of wound healing. Biochem Biophys Res Commun 423:253-258

26. Feng B, Fang Y, Wei SM (2013) Effect and mechanism of epigallocatechin-3-gallate (EGCG) against the hydrogen peroxideinduced oxidative damage in human dermal fibroblasts. J Cosmet Sci 64:35-44

27. Muguel MG (2010) Antioxidant and anti-inflammatory activities of essential oils: a short review. Molecules 15:9252-9287

28. Korkina LG (2007) Phenylpropanoids as naturally occurring antioxidants: from plant defense to human health. Cell Mol Biol 53:15-25

29. Kouba DJ, Chung K-Y, Nishiyama T, Vindevoghel L, Kon A, Klement JF, Uitto J, Mauviel A (1999) Nuclear factor-кB mediates TNF- $\alpha$ inhibitory effect on $\alpha 2$ (I) collagen (COL1A2) gene transcription in human dermal fibroblasts. J Immunol 162:4226-4234

30. Khanna S, Sen CK, Roy S, Christen M-O, Packer L (1998) Protective effects of anethole dithiolethione against oxidative stress-induced cytotoxicity in human Jurkat $\mathrm{T}$ cells. Biochem Pharmacol 56:61-69

31. Tisserand R, Balacs T (1995) Essential oil safety: a guide for health care professionals. Churchill Livingstone, Edinburgh 